\title{
Discussion: Estimates of the Manning"s coefficient for ice-covered rivers
}

1 S. Samuel Li PhD, PEng, MIAHR, MCSCE

Associate Professor, Department of Building, Civil and Environmental Engineering, Concordia University, Montreal, Quebec, Canada
2 Charles Neill MICE

Northwest Hydraulic Consultants, Edmonton, Alberta, Canada

3. David Andres

Northwest Hydraulic Consultants, Edmonton, Alberta, Canada

\section{Contribution by Charles Neill and David Andres}

Li, 2012 has plotted a huge range of composite Manning's $n$ values, between about $0 \cdot 01$ and 0.05 , derived from analysis of winter velocity measurements in ice-covered rivers in Canada. It is difficult to believe that composite values near the lower end of this range could be realistic, since even smooth concrete has an $n$ value of about 0.012 and river beds seldom have values much below $0 \cdot 020$. The abstract states that 'the slope of the energy grade line is difficult to measure... it appears to be about $30 \%$ of the water slope'. This statement suggests that the studied reaches were highly non-uniform, in which case the determinations of the $n$ value are unlikely to be reliable.

Another questionable statement is that 'the composite Manning's coefficients reported... are useful for modelling ice-covered river flow and determining winter discharges. .. particularly when sitespecific data are unavailable'. Even if the reported values were correct, how could they be used for modelling unless they were linked to expected ice conditions and geometric characteristics of the river bed and ice cover, which the author does not discuss at all? The underside of ice covers can exhibit widely different geometries ranging from nearly smooth to highly rough and irregular, depending on the processes of ice accumulation and consolidation during the freeze-up period and on subsequent under-ice transport, accumulation and erosion.

In a previous article (Neill and Andres, 1984) the present contributors analysed the hydraulics of a thick, irregular winter ice cover in 1982 on the Peace River in northern Alberta, Canada. This cover had resulted from the consolidation of a newly formed ice cover by fluctuating discharges released from a reservoir far upstream. The winter cover, which had an average thickness of about $4 \mathrm{~m}$, consisted mainly of slush with embedded ice floes. The slope of both the river bed and the ice surface was approximately $0 \cdot 32 \mathrm{~m} / \mathrm{km}$. The composite Manning $n$ was about $0 \cdot 043$, near the upper end of the author's range, and the bed roughness under open-water conditions was about $0 \cdot 032$, indicating a roughness of about 0.053 for the underside of the ice cover.

\section{Author's reply}

The contributors are correct that a finished concrete surface has a Manning's $n$ value of about 0.012. It is, however, important to note that roughness characteristics differ between concrete and river ice cover. On the underside of ice covers, downward protruding elements (or vertical deviations from the mean position of underside ice cover) can be eroded by water flowing underneath when water temperature rises above a certain threshold; depressing elements can be filled due to temperature fluctuations. This possible mechanism will lead to a reduction in ice-cover roughness. The associated time scale can be short. At the same time scale, water flow in natural rivers is unlikely to reduce the texture of a concrete surface or surface roughness. Thus, it is possible that underside ice cover has a lower Manning's $n$ value than concrete.

On the basis of the difference between the slope of energy grade line and water-surface slope, the contributors point out that the flows were not uniform in the ice-covered river reaches. In fact, natural river flow is rarely uniform at the reach scale. However, the author meant to deal with the flow field in a relatively short channel section, not the reach-scale flow field. In the former case, the assumption of uniform flow would be acceptable, taking into consideration the relatively simple hydraulic and geometric conditions described in the second paragraph of section 2 in $\mathrm{Li}$ (2012).

The use of reported Manning's $n$ values for flow modelling (based on the Saint-Venant equations) would be appropriate if the river channel of interest has basic hydraulic parameters within the range of values given in Table 1 of $\mathrm{Li}$ (2012) and is under similar field conditions as described in the second paragraph of section 2 of Li (2012). For modelling one-dimensional ice-covered river flow, the composite Manning's $n$ ranging between 0.013 and 0.04 may be used to calculate flow resistance distributed along the channel length. For modelling two-dimensional flow, the results shown in Figure 5 of Li (2012) may be used to derive crosschannel distribution of ice Manning's $n$, in addition to alongchannel distribution.

Neill and Andres (1984) presented an interesting case of icecovered river flow, in which the basic hydraulic parameters appear to be outside the range of values given in Table 1 of Li (2012) and the field conditions (slush, ice floes and very large ice 
thickness) are complicated in comparison with those described in section 2 of Li (2012). From back calculations, the contributors obtain an ice Manning's $n$ value of 0.053 from the composite Manning's $n$ value of 0.043 and riverbed Manning's $n$ value of 0.032 ; the calculations have used a commonly made assumption that the presence of ice does not alter the riverbed Manning's $n$. The validity of this assumption is worthy of further investigations.

\section{REFERENCES}

Li SS (2012) Estimates of the Manning's coefficient for icecovered rivers. Proceedings of the Institution of Civil Engineers - Water Management 165(9): 495-505.

Neill CR and Andres DD (1984) Freeze-up flood stages associated with fluctuating reservoir releases. Proceedings of the Third International Specialty Conference on Cold Regions Engineering, CSCE/ASCE, Montreal, Canada, pp. 249-264.

\section{WHAT DO YOU THINK?}

To discuss this paper, please email up to 500 words to the editor at journals@ice.org.uk. Your contribution will be forwarded to the author(s) for a reply and, if considered appropriate by the editorial panel, will be published as a discussion in a future issue of the journal.

Proceedings journals rely entirely on contributions sent in by civil engineering professionals, academics and students. Papers should be 2000-5000 words long (briefing papers should be 1000-2000 words long), with adequate illustrations and references. You can submit your paper online via www.icevirtuallibrary.com/content/journals, where you will also find detailed author guidelines. 